\title{
Pola Dermatom pada Herpes Zoster di Poliklinik Kulit dan Kelamin RSUP Dr. M. Djamil Padang
}

\author{
Putri Sabila Hidayat ${ }^{1}$, Rina Gustia², Satya Wydya Yenny ${ }^{2}$ \\ ${ }^{1}$ Fakultas Kedokteran Universitas Andalas, Padang \\ ${ }^{2}$ Bagian IImu Kesehatan Kulit dan Kelamin Fakultas Kedokteran Universitas Andalas / RSUP Dr. M. Djamil Padang
}

\begin{abstract}
A B S T R A C T
Latar Belakang. Herpes zoster merupakan penyakit yang disebabkan oleh reaktivasi infeksi virus varisela zoster setelah infeksi primer yang bercirikan timbulnya ruam kulit dengan distribusi dermatomal dan disertai rasa nyeri yang hebat. Terdapat kecenderungan peningkatan kasus herpes zoster seiring bertambahnya usia.
\end{abstract}

Objektif. Penelitian ini bertujuan untuk mengetahui pola dermatom pada herpes zoster di Poliklinik Kulit dan Kelamin RSUP Dr. M. Djamil Padang tahun 2015-2017.

Metode. Penelitian ini merupakan penelitian deskriptif. Penelitian ini dilaksanakan Mei 2018 - Agustus 2018. Sampel penelitian sebanyak 18 pasien yang memenuhi kriteria inklusi. Data pasien didapatkan dari rekam medik dan kemudian diolah dan ditampilkan dalam bentuk tabel distribusi frekuensi.

Hasil. Penelitian ini menunjukkan bahwa pola dermatom pasien herpes zoster terbanyak ditemukan di daerah torakal dan area nervus trigeminal (44\%), kelompok usia terbanyak adalah 45-64 tahun (33,3\%). Tidak ada perbedaan kejadian pada laki-laki dan perempuan (50\%). Nyeri merupakan keluhan utama subjektif yang paling sering $(88,2 \%)$ dan munculnya vesikel merupakan keluhan utama objektif terbanyak (92,9\%). Sebagian besar pasien mengalami komplikasi $(72,2 \%)$, komplikasi yang sering terjadi yaitu bagian neurologis (38\%).

Kesimpulan. Lokasi dermatom pasien herpes zoster di Poliklinik Kulit dan Kelamin RSUP Dr. M. Djamil Padang yaitu daerah torakal sebanyak 8 pasien $(44,4 \%)$ dan area nervus trigeminal sebanyak 8 pasien $(44,4 \%)$.

Kata kunci: dermatom, herpes zoster

Background. Herpes zoster is a skin disease caused by reactivation of varicella-zoster virus after its primary infection and characterized by the onset of a skin rash with a dermatomal distribution and accompanied by severe pain. The cases of herpes zoster have tended with increasing age.

Objective. This study was aimed to obtain the dermatome pattern of herpes zoster in the Dermatovenerology Polyclinic of Dr. M. Djamil Hospital Padang period 2015-2017.

Method. This study was a descriptive study that was conducted in May 2018-August 2018. The sample size was 18 patients suited by inclusion criteria. Data were obtained from medical records of herpes zoster patients and presented in the frequency distribution tables.
Result. The results showed that thoracic dermatome and trigeminal nerve area were most commonly involved (44.4\%), within the age range of 45-64 years old (33.3\%). There are no differences in events between men and women (50\%). Pain is the most common major subjective complaint (88.2\%) and classical grouped vesicles are the most major objective complaint (92.9\%). Most patients have complications (72.2\%), a common complication is the neurological (38\%).

Conclusion. The location of dermatomes for herpes zoster patients in the Dermatovenerology Polyclinic of Dr. M. Djamil Hospital Padang was a thoracic region of 8 patients (44.4\%) and a trigeminal nerve area of 8 patients (44.4\%).

Keywords: : dermatome, herpes zoster

\section{Apa yang sudah diketahui tentang topik ini?}

Pola dermatom pasien herpes zoster terbanyak ditemukan di daerah torakal dan area nervus trigeminal.

\section{Apa yang ditambahkan pada studi ini?}

Dermatom yang paling sering dikenai pada herpes zoster diduga berkaitan dengan predileksi dermatom di tempat ruam varisela terbanyak serta persarafan yang tumpang tindih, yaitu di daerah torakal. Hal ini juga dikarenakan dermatom torakal dilalui oleh serabut saraf sensorik yang sensitif, terutama pada bagian interkostal sehingga vesikel akan lebih sering muncul di daerah tersebut. Diikuti lesi di wajah, terutama jika menginfeksi cabang pertama nervus trigeminal yang dapat menimbulkan herpes zoster oftalmikus.

\section{CORRESPONDING AUTHOR}

Name: Putri Sabila Hidayat

Phone: +6281261211921

E-mail:psputri.sabilaa@gmail.com

ARTICLE INFORMATION

Received: September $23^{\text {rd }}$, 2020

Revised: October $15^{\text {th }}, 2020$

Available online: October $31^{\text {st }}, 2020$ 


\section{Pendahuluan}

Penyakit kulit menurut data profil kesehatan Indonesia tahun 2009 menempati peringkat 3 dari 10 penyakit pada pasien rawat jalan di rumah sakit Indonesia dan merupakan salah satu masalah dalam bidang kesehatan yang meningkat tiap tahunnya. ${ }^{1}$ Penyakit infeksi kulit menempati peringkat 3 dari 10 penyakit terbanyak di Kota Padang tahun 2014 sebanyak 15.556 kasus. Hal ini menunjukkan bahwa penyakit infeksi kulit masih sering terjadi di Indonesia, terutama di Kota Padang. ${ }^{2}$

Herpes Zoster (HZ) biasa disebut shingles, merupakan penyakit kulit infeksi akibat reaktivasi virus varisela zoster (VVZ) setelah infeksi primer yang bermanifestasi pada kulit dan mukosa. ${ }^{3}$ Hampir satu dari tiga orang di Amerika Serikat akan mengalami herpes zoster selama masa hidup mereka. ${ }^{4}$ Angka kejadian di Amerika Serikat setiap tahunnya diperkirakan sebanyak satu juta kasus, dengan rata-rata 3-4 kasus per 1000 penduduk. $^{5}$ Estimasi kejadian herpes zoster di Eropa sekitar 3,4 - 4,82 per 1000 penduduk per tahun dan meningkat menjadi lebih dari 11 per 1000 penduduk per tahun pada usia minimal 80 tahun. ${ }^{6}$

Insiden herpes zoster meningkat seiring bertambahnya usia dan berkaitan dengan menurunnya sistem imunitas tubuh pada seseorang. ${ }^{7}$ Penyakit ini lebih sering menyerang pasien dewasa dibandingkan anak-anak. ${ }^{8}$ Puncak kasus herpes zoster terjadi pada usia 45-64 tahun berdasarkan data pada 13 rumah sakit pendidikan di Indonesia pada tahun 2011-2013. ${ }^{3}$ Kejadian herpes zoster pada usia lebih dari 50 tahun dapat mencapai 66\%. ${ }^{9}$ Selain pada peningkatan usia, juga dapat terjadi pada pasien imunokompromais seperti pasien HIV-AIDS, pasien dengan keganasan, dan pasien yang mendapat obat imunosupresi atau transplantasi organ. ${ }^{7}$

Dermatom merupakan area di kulit yang menerima informasi sensorik dari saraf spinalis. Saraf spinalis terdiri dari 31 pasang saraf; 8 servikal, 12 torakal, 5 lumbal, 5 sakral, dan 1 koksigeal.10 Pada saat sistem imun seseorang menurun maka akan terjadi reaktivasi VVZ, kemudian sel $\mathrm{T}$ akan membawa virus sepanjang ganglia dorsalis atau kranialis. ${ }^{11}$ Infeksi VVZ pada ganglia radiks dorsalis akan menimbulkan nyeri disepanjang dermatom sesuai tempat persarafan yang terinfeksi. ${ }^{12}$ VVZ merambat secara sentrifugal disepanjang percabangan saraf menuju dermatom tertentu. ${ }^{13}$

Dermatom yang sering dikenai adalah daerah dada (torakal) sekitar T5 hingga T12, diikuti area nervus trigeminal yang menyebabkan herpes zoster oftalmikus, daerah saraf kranial, dan daerah dermatom lumbosakral. ${ }^{14}$ Data di Poliklinik Kulit dan Kelamin RSUP Sanglah Denpasar bulan Januari 2010 sampai Desember 2014, didapatkan 322 pasien herpes zoster $(2,05 \%)$ dari total kunjungan pasien sebanyak 15.664 pasien. Kelompok umur tersering adalah usia 51-60 tahun sebanyak 75 pasien $(23,3 \%)$. Distribusi dermatom tersering herpes zoster adalah torakal (58,6\%), oftalmika $(17,3 \%)$, lumbosakral $(9,3 \%)$, fasial $(6,6 \%)$, generalisata $(5,3 \%)$ dan servikal $(4,0 \%) .15$

Hal ini diduga berkaitan dengan predileksi dermatom di tempat ruam varisela terbanyak, yaitu di daerah torakal.11 Banyaknya predileksi di daerah torakal dengan gejala awal nyeri sebelum munculnya ruam dan vesikel mengakibatkan dokter kesulitan dalam mendiagnosis herpes zoster. Kelainan motorik segmental ditemukan pada beberapa kasus, tetapi karena herpes zoster sering ditemukan pada area torakal, kelainan tersebut tidak terlalu berarti secara fungsional dan luput dari perhatian pasien. Hal ini mengakibatkan keterlambatan diagnosis dan tatalaksana sehingga meningkatkan risiko terjadinya komplikasi.3,14

Komplikasi tersering herpes zoster adalah neuralgia paska herpes (NPH). Neuralgia pasca herpes merupakan nyeri yang timbul lebih dari 90 hari setelah penyakit sembuh pada tempat bekas penyembuhan. ${ }^{9}$ Penyakit ini cenderung timbul pada usia di atas 40 tahun, dengan puncak kasus NPH pada usia 45-64 tahun. Total kasus NPH di Indonesia adalah 593 kasus $(26,5 \%$ dari total kasus HZ).3,8 Neuralgia paska herpes dan berbagai komplikasi lainnya sebagian besar diakibatkan karena keterlambatan diagnosis. Hal ini dikarenakan lebih dari 53\% dokter mendapat kesulitan dalam mendiagnosis herpes zoster sebelum muncul ruam kulit. 3

Jumlah kasus herpes zoster di Poliklinik Kulit dan Kelamin RSUP Dr. M. Djamil Padang tahun 2015 berdasarkan data rekam medik yaitu sebanyak 6 kasus. Data tahun 2016 menunjukkan peningkatan kasus yaitu menjadi 14 kasus, sedangkan tahun 2017 yaitu sebanyak 17 kasus. ${ }^{16}$ 
Penelitian mengenai pola dermatom pada herpes zoster di Indonesia khususnya di Poliklinik Kulit dan Kelamin RSUP Dr. M. Djamil Padang sendiri belum tersedia. Berdasarkan ulasan diatas, peneliti tertarik melakukan penelitian mengenai bagaimana pola dermatom pada pasien herpes zoster di Poliklinik Kulit dan Kelamin RSUP Dr. M. Djamil Padang pada tahun 2015-2017.

\section{Metode}

Penelitian ini merupakan penelitian deskriptif retrospektif, yakni dengan cara mengumpulkan data dari rekam medis pasien herpes zoster di RSUP Dr. M. Djamil Padang. Penelitian ini dilakukan di bagian Rekam Medis RSUP Dr. M. Djamil Padang dari Desember 2017 sampai Desember 2018.

Populasi penelitian adalah pasien yang didiagnosis herpes zoster dan tercatat di Rekam Medis RSUP Dr. M. Djamil Padang tahun 2015 2017 dengan sampel yang memenuhi kriteria inklusi (penderita yang didiagnosis herpes zoster dan tercatat di rekam medis) dan kriteria eksklusi (data rekam medis pasien yang tidak lengkap sehubungan dengan data yang akan diambil dan diteliti yang tercatat di rekam medis). Data diolah dan digunakan analisis univariat.

\section{Hasil}

Data pasien herpes zoster di Poliklinik Kulit dan Kelamin RSUP Dr. M. Djamil Padang periode Januari 2015 - Desember 2017 didapatkan 18 orang yang memenuhi kriteria inklusi dan eksklusi.

\section{Pola Dermatom Pasien Herpes Zoster}

Tabel 1. Distribusi Penderita Herpes Zoster Berdasarkan Pola Dermatom

\begin{tabular}{lcc}
\hline \multicolumn{1}{c}{ Pola Dermatom } & f & \% \\
\hline Area nervus trigeminal & 8 & 44,4 \\
Servikal & 2 & 11,1 \\
Servikotorakal & - & - \\
Torakal & 8 & 44,4 \\
Torakolumbal & - & - \\
Lumbal & - & - \\
Lumbosakral & - & - \\
Sakral & - & - \\
\hline \multicolumn{1}{c}{ Total } & 18 & 100,0 \\
\hline
\end{tabular}

Berdasarkan tabel 1 didapatkan dua teratas lokasi dermatom pasien herpes zoster di Poliklinik Kulit dan Kelamin RSUP Dr. M. Djamil Padang yaitu daerah torakal sebanyak 8 pasien
$(44,4 \%)$ dan area nervus trigeminal sebanyak 8 pasien $(44,4 \%)$.

\section{Usia Pasien}

Tabel 2. Distribusi Penderita Herpes Zoster Berdasarkan

\begin{tabular}{ccc} 
Usia & f & $\mathbf{\%}$ \\
\hline Usia & 0 & - \\
\hline 5 Tahun & 1 & 5,6 \\
15-24 tahun & 4 & 22,2 \\
25-44 Tahun & 2 & 11,1 \\
45-64 Tahun & 6 & 33,3 \\
$\geq 65$ Tahun & 5 & 27,8 \\
\hline Total & 18 & 100,0 \\
\hline
\end{tabular}

Hasil penelitian berdasarkan usia pada tabel 2 menunjukkan penderita herpes zoster di Poliklinik Kulit dan Kelamin RSUP Dr. M. Djamil Padang terbanyak berusia 45-64 tahun sebanyak 6 pasien $(33,3 \%)$.

\section{Jenis Kelamin Pasien}

Tabel 3. Distribusi Penderita Herpes Zoster Berdasarkan Jenis Kelamin

\begin{tabular}{ccc}
\hline Jenis Kelamin & f & \% \\
\hline Laki-laki & 9 & 50,0 \\
Perempuan & 9 & 50,0 \\
\hline Total & 18 & 100,0 \\
\hline
\end{tabular}

Berdasarkan tabel 3 didapatkan bahwa tidak ada perbedaan kejadian herpes zoster pada lakilaki dan perempuan di Poliklinik Kulit dan Kelamin RSUP Dr. M. Djamil Padang.

\section{Keluhan Utama Pasien}

Tabel 4. Distribusi Penderita Herpes Zoster Berdasarkan Keluhan Utama

\begin{tabular}{|c|c|c|}
\hline Keluhan Utama & $\mathbf{f}$ & $\%$ \\
\hline \multicolumn{3}{|l|}{ Subjektif } \\
\hline Nyeri & 15 & 88,2 \\
\hline Gatal & 2 & 11,8 \\
\hline Total & 17 & 100,0 \\
\hline \multicolumn{3}{|l|}{ Objektif } \\
\hline Demam & 1 & 7,1 \\
\hline Tukak & - & - \\
\hline Gelembung berisi & 13 & 92,9 \\
\hline \multicolumn{3}{|l|}{ Cairan } \\
\hline Total & 14 & 100,0 \\
\hline
\end{tabular}

Berdasarkan data penelitian pasien herpes zoster di Poliklinik Kulit dan Kelamin RSUP Dr. M. Djamil Padang pada tabel 4 didapatkan bahwa keluhan utama bersifat subjektif terbanyak adalah nyeri sebanyak 15 pasien $(88,2 \%)$ dan diikuti gatal sebanyak 2 pasien $(11,8 \%)$. Keluhan utama bersifat objektif terbanyak adalah munculnya 
vesikel sebanyak 13 pasien $(92,9 \%)$ dan diikuti demam pada 1 pasien $(7,1 \%)$.

\section{Komplikasi Pasien}

Tabel 5. Distribusi Penderita Herpes Zoster Berdasarkan Komplikasi

\begin{tabular}{lcc}
\hline \multicolumn{1}{c}{ Komplikasi } & f & $\mathbf{\%}$ \\
\hline Komplikasi & 13 & 72,2 \\
Tidak Ada komplikasi & 5 & 27,8 \\
\hline \multicolumn{1}{c}{ Total } & 18 & 100,0 \\
\hline Komplikasi & & \\
Kutaneus & 3 & 23,0 \\
Neurologis & 5 & 38,5 \\
Mata & 4 & 30,8 \\
THT & 1 & 7,7 \\
Viseral & - & - \\
\hline \multicolumn{1}{c}{ Total } & 13 & 100,0 \\
\hline
\end{tabular}

Berdasarkan data penelitian pasien herpes zoster di Poliklinik Kulit dan Kelamin RSUP Dr. M. Djamil Padang pada tabel 5 didapatkan bahwa sebagian besar pasien mengalami komplikasi $(72,2 \%)$. Komplikasi yang sering terjadi pada bagian neurologis yaitu neuralgia paska herpes (NPH) sebanyak 5 pasien $(38,5 \%)$. Komplikasi bagian mata yaitu blefarokeratokonjungtivitis, skleritis, uveitis, dan keratitis numularis ditemukan pada 4 pasien $(30,8 \%)$. Komplikasi bagian kutaneus seperti infeksi sekunder ditemukan pada 3 pasien (23\%), diikuti bagian THT yaitu Sindrom Ramsay Hunt pada 1 pasien $(7,7 \%)$.

\section{Pembahasan}

\section{Pola Dermatom Herpes Zoster}

Berdasarkan data penelitian didapatkan dua teratas lokasi dermatom pasien herpes zoster di Poliklinik Kulit dan Kelamin RSUP Dr. M. Djamil Padang periode Januari 2015-Desember 2017 adalah torakal sebanyak 8 pasien $(44,4 \%)$ dan area nervus trigeminal sebanyak 8 pasien $(44,4 \%)$, sedangkan sisanya yaitu servikal sebanyak 2 pasien $(11,1 \%)$. Hasil tersebut sesuai dengan penelitian di India Utara tahun 2016 mengenai lokasi dermatom tersering pada penderita herpes zoster yaitu daerah torakal sebanyak 20 orang (40\%).17 Penelitian lain di India pada tahun 2010 mendapatkan bahwa area nervus trigeminal menjadi lokasi tersering pada penderita herpes zoster sebanyak 18 orang $(43,9 \%){ }^{18}$ Distribusi dermatom tersering herpes zoster di Poliklinik Kulit dan Kelamin RSUP Sanglah Denpasar bulan Januari 2010 sampai
Desember 2014 yaitu daerah torakal (58,6\%) kemudian diikuti area nervus trigeminal $(17,3 \%) \cdot{ }^{15}$

Herpes zoster terjadi akibat reaktivasi VVZ ketika sistem imun seseorang menurun dan merambat secara sentrifugal disepanjang percabangan saraf menuju dermatom tertentu. ${ }^{11,13}$ Dermatom yang paling sering dikenai pada herpes zoster diduga berkaitan dengan predileksi dermatom di tempat ruam varisela terbanyak serta persarafan yang tumpang tindih, yaitu di daerah torakal.11,19 Hal ini juga dikarenakan dermatom torakal dilalui oleh serabut saraf sensorik yang sensitif, terutama pada bagian interkostal sehingga vesikel akan lebih sering muncul di daerah tersebut. ${ }^{13,20}$ Diikuti lesi di wajah, terutama jika menginfeksi cabang pertama nervus trigeminal yang dapat menimbulkan herpes zoster oftalmikus. ${ }^{14}$ Hasil penelitian ini sesuai dengan penelitian di RSUP Sanglah Denpasar tahun 2011-2013 oleh Ningrat yang menemukan bahwa pola dermatom tersering pada pasien herpes zoster adalah dermatom torakal, kemudian diikuti area nervus trigeminal. ${ }^{20}$ Munculnya lesi pada dermatom torakal ini harus diberikan perhatian, karena apabila mengenai neuron pada kornu anterior medula spinalis dapat menyebabkan mielitis, defisit fungsi motorik dan vegetatif. 21

\section{Usia Pasien Herpes Zoster}

Berdasarkan hasil penelitian pada pasien herpes zoster menunjukkan penderita herpes zoster di Poliklinik Kulit dan Kelamin RSUP Dr. M. Djamil Padang periode Januari 2015-Desember 2017 terbanyak berusia 45-64 tahun sebanyak 6 pasien $(33,3 \%)$, diikuti usia $\geq 65$ tahun sebanyak 5 pasien $(27,78 \%)$. Hasil penelitian ini sesuai dengan data pada 13 rumah sakit pendidikan di Indonesia pada tahun 2011-2013 dengan puncak kasus herpes zoster berusia 45-64 tahun $(37,95 \%){ }^{3}$ Hasil tersebut juga sesuai dengan penelitian di India Utara tahun 2016 mengenai usia tersering pada penderita herpes zoster yaitu 41-60 tahun sebanyak 25 pasien (50\%). ${ }^{17}$ Penelitian lain di Poliklinik Kulit dan Kelamin RSUP Prof. Dr. R. D. Kandou Manado tahun 2013 didapatkan usia penderita herpes zoster terbanyak terdapat pada usia 45-64 tahun $(78,57 \%)^{22}$ 
Insiden herpes zoster pada usia 20-50 tahun sebanyak 2,5 per 1.000 orang, meningkat menjadi 7 per 1.000 orang pada usia 60 tahun, dan mencapai 10 per 1.000 orang pada usia 80 tahun. $^{3}$ Kejadian herpes zoster meningkat seiring dengan peningkatan usia sekitar 7-11 per 1.000 penduduk per tahun pada usia lebih dari 60 tahun di Eropa dan Amerika Utara. Diperkirakan lebih dari satu juta kasus baru herpes zoster terjadi tiap tahunnya dan lebih dari satu setengahnya terjadi pada usia lebih dari 60 tahun. ${ }^{11}$

Usia saat pertama kali terinfeksi VVZ mempengaruhi usia munculnya herpes zoster. Seseorang yang terinfeksi saat di dalam kandungan atau pada awal kehidupan berisiko mengalami pediatric zoster. Risiko herpes zoster akan semakin meningkat jika terinfeksi VVZ saat anak-anak. ${ }^{6}$ Infeksi primer VVZ sebanyak 90\% kasus terjadi pada anak usia kecil dari 10 tahun. Hal ini menyebabkan peningkatan insiden herpes zoster pada usia tua. ${ }^{23}$

Peran penting usia sebagai faktor risiko herpes zoster diduga berkaitan dengan hilangnya respon imunitas seluler spesifik sel akibat penuaan. ${ }^{6}$ Sistem imunitas tubuh akan semakin menurun seiring dengan peningkatan usia.3,5 Hilangnya kekebalan tubuh tersebut memungkinkan VVZ untuk menyelesaikan proses reaktivasi dan menyebar ke epidermis dan menimbulkan gejala klinis. ${ }^{6}$ Rendahnya angka kejadian pada usia muda dikarenakan adanya fase dorman yang cukup panjang dari reaktivasi varisela menjadi herpes zoster. ${ }^{20}$

\section{Jenis Kelamin Pasien Herpes Zoster}

Prevalensi kasus herpes zoster yang tercatat di Poliklinik Kulit dan Kelamin RSUP Dr. M. Djamil Padang periode Januari 2015-Desember 2017 adalah 18 kasus, yang terdiri atas 50\% laki-laki dan $50 \%$ perempuan. Pada penelitian ini, didapatkan bahwa tidak ada perbedaan kejadian herpes zoster pada laki-laki dan perempuan. Hal ini sesuai dengan kepustakaan dan penelitian pada tahun 2017 yang mendapatkan bahwa frekuensi herpes zoster pada laki-laki dan perempuan sama.7,8

Berbeda dengan penelitian di Amerika Serikat didapatkan bahwa insiden herpes zoster lebih tinggi pada perempuan dibandingkan laki-laki.24 Studi di Belanda juga mendapatkan 38\% kasus lebih banyak terjadi dikalangan perempuan daripada laki-laki.6 Penelitian di Poliklinik Kulit dan Kelamin RSUP Prof. Dr. R.D. Kandou Manado tahun 2013 didapatkan herpes zoster pada perempuan 57,14\% sedangkan pada laki-laki $42,86 \% .{ }^{22}$ Hal ini diduga karena perempuan memiliki respon imun yang berbeda terhadap infeksi virus yang laten dan kecenderungan mencari pengobatan lebih tinggi dibandingkan laki-laki. Secara umum perempuan juga lebih sering berkontak dengan anak-anak daripada lakilaki, termasuk dengan anak yang menderita varisela dan tingkat morbiditas perempuan terhadap suatu penyakit lebih tinggi dibandingkan laki-laki. ${ }^{20,24}$ Sementara itu, hasil studi di Pakistan cenderung menunjukkan insiden herpes zoster lebih tinggi pada laki-laki.25 Alasan yang mendasari perbedaan insiden herpes zoster berdasarkan jenis kelamin masih belum jelas. Beberapa peneliti tidak menemukan perbedaan berdasarkan jenis kelamin pada kejadian herpes zoster.6,24

\section{Keluhan Utama Pasien Herpes Zoster}

Berdasarkan data penelitian pasien herpes zoster di Poliklinik Kulit dan Kelamin RSUP Dr. M. Djamil Padang periode Januari 2015-Desember 2017 didapatkan bahwa keluhan utama bersifat subjektif terbanyak adalah nyeri sebanyak 15 pasien $(88,2 \%)$ dan diikuti gatal sebanyak 2 pasien $(11,8 \%)$. Keluhan utama bersifat objektif terbanyak adalah munculnya vesikel sebanyak 13 pasien $(92,9 \%)$ dan diikuti demam pada 1 pasien $(7,1 \%)$.

Hal ini sesuai dengan kepustakaan yang menyatakan bahwa $90 \%$ pasien mengeluhkan nyeri sebagai keluhan utama. ${ }^{23}$ Penelitian lain di RSUD Dr. Soetomo Surabaya tahun 2010-2013 menunjukkan sebanyak 118 pasien baru (100\%) datang dengan nyeri sebagai keluhan utama bersifat subjektif dan munculnya vesikel sebagai keluhan utama bersifat objektif. ${ }^{26} \mathrm{Hal}$ yang sama juga didapatkan Cebrian-Cuenca et al. tahun 2010 dalam penelitiannya menyatakan sebanyak $77,7 \%$ pasien mengeluh nyeri dari 146 pasien. ${ }^{27}$ Studi Costache mendapatkan $94 \%$ pasien mengeluh nyeri sebagai keluhan utama. ${ }^{13}$ Nyeri yang bersifat unilateral dermatomal dirasakan pasien 2-3 hari sebelum munculnya ruam di kulit. Berdasarkan literatur nyeri yang dirasakan penderita herpes zoster dapat berupa paraestesi (kesemutan), diestesi (sangat sensitif bila disentuh), alodinia 
(rasa nyeri namun tidak sesuai dengan rangsangan), dan hiperestesi (rasa nyeri yang berlebihan atau berkepanjangan). Nyeri tersebut dapat terjadi secara kontinu atau hilang timbul. ${ }^{5}$ Akibat dari rasa nyeri yang lebih dominan sebelum munculnya ruam menyebabkan pasien mengeluh nyeri sebagai keluhan utama. ${ }^{23}$

\section{Komplikasi Pasien Herpes Zoster}

Berdasarkan data penelitian pasien herpes zoster di Poliklinik Kulit dan Kelamin RSUP Dr. M. Djamil Padang periode Januari 2015-Desember 2017 didapatkan bahwa sebagian besar pasien mengalami komplikasi (72,2\%) dengan komplikasi yang sering terjadi yaitu bagian neurologis sebanyak 5 pasien (38\%). Komplikasi neurologis tersering herpes zoster adalah neuralgia paska herpes (NPH), merupakan nyeri yang timbul lebih dari 90 hari setelah penyakit sembuh pada tempat bekas penyembuhan. ${ }^{9}$ Penyakit ini cenderung timbul pada usia di atas 40 tahun, dengan puncak kasus NPH pada usia 45-64 tahun dengan total kasus NPH di Indonesia adalah 593 kasus (26,5\% dari total kasus HZ). ${ }^{8}$ Kejadian dan derajat keparahan herpes zoster dan NPH meningkat secara signifikan seiring dengan peningkatan usia. Pasien yang menderita herpes zoster berisiko $10-70 \%$ menderita NPH. ${ }^{27} \mathrm{Hal}$ ini sesuai dengan penelitian di Poliklinik Kulit dan Kelamin RSUP Dr. M. Djamil Padang yang mendapatkan bahwa usia pasien yang menderita NPH sebagian besar di atas 60 tahun. Hal yang sama juga didapatkan pada sebuah studi di Pakistan tahun 2016 yang melaporkan insiden NPH paling sering terjadi pada $50 \%$ pasien usia lanjut dan mengakibatkan penurunan kualitas hidup. ${ }^{17,25}$ Neuralgia paska herpes dan berbagai komplikasi lainnya sebagian besar diakibatkan karena keterlambatan diagnosis. Hal ini dikarenakan lebih dari 53\% dokter mendapat kesulitan dalam mendiagnosis herpes zoster sebelum munculnya ruam kulit. $^{3}$

\section{Simpulan}

Berdasarkan hasil penelitian ini didapatkan kesimpulan bahwa pola dermatom pada pasien herpes zoster yang terbanyak adalah torakal dan area nervus trigeminal. Usia pasien herpes zoster terbanyak adalah 45-64 tahun. Tidak ada perbedaan kejadian herpes zoster pada pria dan wanita. Keluhan utama pasien herpes zoster bersifat subjektif terbanyak adalah nyeri dan bersifat objektif terbanyak yaitu munculnya vesikel. Sebagian besar pasien mengalami komplikasi yaitu bagian neurologis (Neuralgia Paska Herpes).

\section{Ucapan Terima Kasih}

Ucapan terima kasih peneliti sampaikan kepada seluruh pihak yang turut membantu dalam menyelesaikan penelitian ini.

\section{Daftar Pustaka}

1. Kementrian Kesehatan RI. Profil kesehatan Indonesia 2009. 2010.

2. Dinas Kesehatan Kota Padang. Profil kesehatan kota Padang tahun 2014. 2015.

3. Pusponegoro EHD, Nilasari H, Lumintang H, Niode NJ, Daili SF, Djauzi S, editors. Buku panduan herpes zoster di Indonesia 2014. Jakarta: Fakultas Kedokteran Universitas Indonesia;2014.

4. United States Centers for Disease Control and Prevention. Shingles Surveillance. http://www.cdc.gov/shingles/surveillance.html Diakses 14 Desember 2017. 2014.

5. Jeffrey I, Cohen MD. Herpes zoster. NEJM. 2013;369:255-63.

6. Johnson RW, Alvarez-Pasquin MJ, Bijl M, Franco E, Gaillat J, Clara JG, et al. Herpes zoster epidemiology, management, and disease and economic burden in Europe: a multidisciplinary perspective.2015;3(4):109-120.

7. Janniger CK. Herpes zoster. https://emedicine.medscape.com/1132465- Diakses Desember 2017. 2017.

8. Handoko RP. Penyakit virus. In : Djuanda A, Hamzah M, Aisah S, editors. Ilmu Penyakit Kulit dan Kelamin. Edisi ke-6. Jakarta: Fakultas Kedokteran Universitas Indonesia;2010.p.110-1.

9. Johnson RW. The impact of herpes zoster and postherpetic-neuralgia on quality of life. BMC Medicine Journal. 2010;8:37-42.

10. Kishner S. Dermatomes Anatomy. Medscape. https://emedicine.medscape.com/article/1878388overview - Diakses Desember 2017. 2017.

11. Schmader KE, Oxman MN. Varicella and herpes zoster. In: Goldsmith LA, Katz SI, Gilchrest BA, Paller AS. Leffell DJ, Wolff K, Schmader KE, editors. Fitzpatrick's Dermatology in General Medicine $7^{\text {th }}$ ed. United States: McGraw-Hill; 2008.p.1885-194.

12. Duus $P$, Baehr M, Frotscher M. Duu's topical diagnosis in neurology. 4th ed. Germany: Georg Thieme Verlag; 2005.p.71-72.

13. Costache $C$, Costache D. A study of the dermatomes in herpes zoster. Bulletin of the Transilvania University of Brasov. 2009;2(51):19-24.

14. Mueller NH, Gilden DH, Cohrs RJ. Varicella-zoster virus infection: Clinical features, molecular pathogenesis of the disease, and latency. Neurol Clin. 2008;26:675-97.

15. Santosa C. Profil penyakit herpes zoster pada pasien di Poliklinik Rawat Jalan RSUP Sanglah Denpasar Bali tahun 2010-2014. Denpasar:Universitas Udayana; 2015. 
16. Instalasi Rekam Medik RSUP. Dr. M. Djamil Padang. Data unit rekam medik herpes zoster tahun 20152017 instalasi rawat jalan. Padang; 2017.

17. Puri N. A study on the clinical presentation of herpes zoster in a district hospital in North India. JPAD. 2016;133-6.

18. Uddin MR, Bhuyain MMH, Akhter F. Study on morphological and clinical characteristics of herpes zoster in a tertiary medical college hospital. JPAD. 2010;80-2.

19. Reeves AG. Disorders of the nervous system. London: Year Book Medical Publishers;1981.p.90.

20. Ningrat DAAA, Darmada IGK. Gambaran karakteristik herpes zoster di Poliklinik Kulit dan Kelamin RSUP. Sanglah Denpasar periode Januari 2011- Desember 2013. E-Jurnal Medika. 2017;9:22-24.

21. Arvin AM. Varicella-zoster virus. CMR.1996;9(3)36181.

22. Dilly JT, Kapantow MG, Suling PL. Profil herpes zoster di Poliklinik Kulit dan Kelamin RSUP. Prof. Dr. R. D. Kandou Manado periode Januari - Desember 2013. Jurnal e-clinic. 2016;4:2.

23. McCrary ML, Severson J, Tyring SK. Varicella-zoster virus. J Am Acad Dermatol.1999;41(1):1-13.

24. Insinga RP, Itzler RF, Pellissier JM, Saddier P, Nikas AA. The incidence of herpes zoster in a United States administrative database. J Gen Intern Med. 2005;20(8):748-53.

25. Malkud S, Dyavannanavar V, Purnachandra, Murthy KS. Clinical and morphological characteristics of herpes zoster - A study from the tertiary care center. JPAD. 2016;26(3):219-222.

26. Ayuningati LK, Indramaya DM. Karakteristik pasien herpes zoster di RSUD Dr. Soetomo Surabaya tahun 2010-2013. E-Journal UNAIR. 2015;27:211-217.

27. Cebrian-Cuenca AM, Domingo JD, Rodriguez MS, Barbera JP, Perez JN. Epidemiology of herpes zoster infection among patients treated in primary care centers in the Valencian Community (Spain). BMC Family Practice.2010;11(33):1-7. 